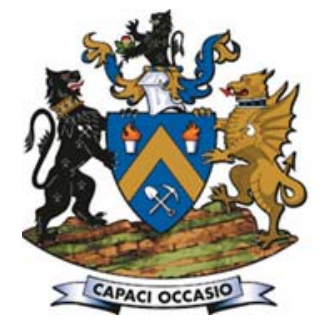

\title{
Prediction of the spontaneous combustion liability of coals and coal shales using statistical analysis
}

\author{
by M. Onifade and B. Genc
}

\section{Synopsis}

In this study we investigate the intrinsic factors influencing the propensity of coals and coal shales to undergo spontaneous combustion using statistical analysis. The intrinsic properties were determined by testing 14 in situ bituminous coals and 14 coal shales from the Witbank coalfield, South Africa. The relationships between these intrinsic properties (obtained from proximate and ultimate analysis) and spontaneous combustion liability indices (the Wits-Ehac Index and the Wits-CT Index) were established using linear and multiple regression analysis based on set criteria. The linear regression analyses indicate that moisture, volatile matter, ash, carbon, hydrogen, and nitrogen contents are the main factors affecting the spontaneous combustion liability of coals, while moisture, volatile matter, ash, carbon, hydrogen, nitrogen and total sulphur contents are the factors affecting the spontaneous combustion liability of coal shales. The regression analysis shows either a positive or a negative correlation coefficient between the intrinsic factors and the spontaneous combustion liability index. Multiple regression of the spontaneous combustion liability index on eight independent variables was used to develop acceptable and reliable predictive models as indicated by high $\mathrm{R}$ squared values, high correlation coefficients, and low standard error of estimates. The use of the models derived from this study may enable the spontaneous combustion liability of coals and coal shales to be reliably predicted.

\section{Keywords}

spontaneous combustion, coal, coal shale, statistical analysis, Wits-Ehac Index, Wits-CT Index.

\section{Introduction}

Self-heating causes an increase in temperature without the contribution of heat from external sources. The reaction between coal and oxygen provides enough energy to support combustion without the influence of an external heat source (Onifade and Genc, 2018a).

Spontaneous combustion in spoil heaps, waste dumps, highwalls, and coal shales is similar to coal oxidation. The self-heating of coal with a potential transition into endogenous fire constitutes a direct safety hazard in both underground and opencast mines, and unfavourably influences the mine environment. Most heat transfer may be by conduction, convection or radiation to the surrounding strata (Akande and Onifade, 2013; Akande, Onifade, and Aladejare, 2013). Rocks tend to be good insulators and retain heat within a coal seam or spoil heap. Selfheating as the major cause of coal shale and spoil heap fires is due to the accumulated influence of heat generating and heat dissipating mechanisms.

Coal and coal shale are sedimentary rocks that contain considerable amounts of organic and inorganic constituents (Dullien, 1979; Onifade and Genc, 2018b). This renders the rock permeable to water and air, and increases its surface area, thereby making the organic particles reactive to facilitate oxidation (Dullien, 1979). Extensive research has been conducted experimentally and computationally on the self-heating of coal in both surface and underground mines (Carras and Young, 1994; Genc and Cook, 2015; Kucuk, Kadioglu, and Gulaboglu, 2003; Stracher and Taylor, 2004). However, only limited studies have been conducted towards understanding the spontaneous combustion liability of coal shales exposed to atmospheric oxygen (Onifade, Genc, and Carpede, 2018; Onifade and Genc, 2018c; Onifade and Genc, 2018b).

Self-heating of coals and coal shales has been found to cause spontaneous combustion in selected bands of coal seams, highwalls, and spoil heaps (Onifade, Genc, and Carpede, 2018; Onifade and Genc, 2018c; Onifade and Genc, 2018b) (Figure 1). There is not sufficient information to evaluate and compare the spontaneous combustion liability of coal shales in relation to coals.

Different intrinsic and extrinsic factors affecting self-heating are the reason for the lack of better understanding of the mechanism of spontaneous combustion. These factors have been documented in various studies to predict the spontaneous combustion liability of coal (Banerjee, 1985; Beamish and Blazak,

* School of Mining Engineering, University of the Witwatersrand, South Africa.

(C) The Southern African Institute of Mining and Metallurgy, 2018. ISSN 2225-6253. This paper was first presented at the Society of Mining Professors 6th Regional Conference 2018, 12-13 March 2018, Birchwood Hotel and Conference Centre, Johannesburg, South Africa. 


\section{Prediction of the spontaneous combustion liability of coals and coal shales}
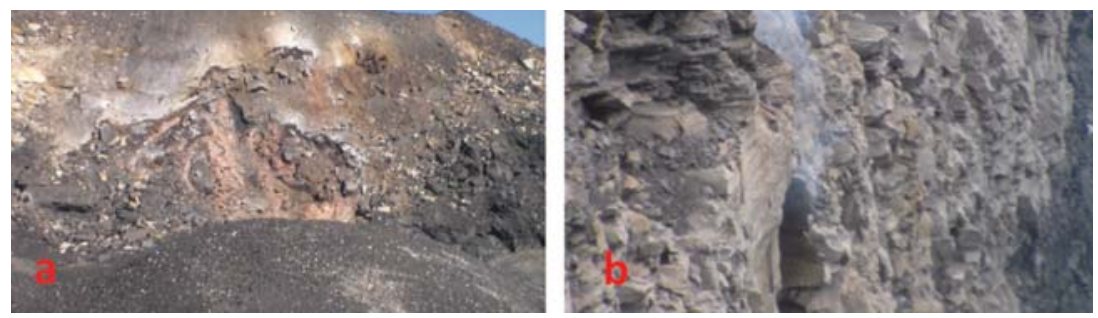

Figure 1-(a) Spoil heaps at Tweefontein Mine, (b) self-heating of coal shale away from the coal seam at Goedgevonden Colliery, Witbank, South Africa (Onifade and Genc, 2018b)

2005; Falcon, 2004; Guney, 1968; Kaymakci and Didari, 2002; Kim, 1977; Onifade and Genc, 2018b; Panigrahi and Sahu, 2004; Panigrahi and Sexana, 2001; Ren, Edwards, and Clarke, 1999). In the present work, selected intrinsic properties (moisture, ash, volatile, carbon, nitrogen, hydrogen, and, sulphur contents) of coals and coal shales were studied following standard procedures of the American Society for Testing and Materials (ASTM) and International Organization for Standardization (ISO). A statistical interpretation was carried out on coal and coal shale analysis data, and selected intrinsic factors affecting their liability toward spontaneous combustion examined. The combined effects of the selected intrinsic factors on the self-heating potential of these materials were evaluated for predictive purposes using multiple regression analysis. This will be useful for establishing significant relationships between coal and coal shale in terms of spontaneous combustion.

\section{Materials and methods}

\section{Sample collection}

Fourteen bituminous coals and fourteen coal shales were obtained from four coal mines in the Witbank coalfield using the ply sampling technique. Ply sampling provides a representation of the analysis of all the coal and mineral constituents in the seam as a whole. The samples were collected between selected bands of the coal seams (above and below) and highwalls, and sealed in airtight bags (made of aluminium-coated polyester) to avoid moisture loss and oxidation.

\section{Sample preparation}

Samples of coal and coal shale were reduced by crushing and ball milling to suitable sizes ( $<250 \mu \mathrm{m}$ for geochemical analysis and $<212 \mu \mathrm{m}$ for spontaneous combustion tests) to obtain representative samples as required for each test. Volatile matter, ash content, moisture content, and fixed carbon were determined according to ASTM D-3175, D-3174, and D-3173. Carbon, hydrogen, nitrogen, and sulphur were determined using a LECO TruSpec CHNS analyser, after calibration with sulfamethazine according to ISO 12902:2001. The data processing was done by the software incorporated in the instrument. The results are given in percentages of carbon, hydrogen, and sulphur in the sample. The results for proximate, elemental analysis (percentage, air-dried basis), and spontaneous combustion tests (WitsEhac and Wits-CT Index) carried out on each sample are presented in Tables I and II.

\section{Wits-Ehac tests}

The Wits-Ehac Index was developed in the late 1980s to test the spontaneous combustion liability of coal (Eroglu, 1992; Genc, Onifade. and Cook, 2018; Genc and Cook, 2015; Onifade, Genc, and Carpede, 2018; Onifade and Genc, 2018b, 2018c, 2018d, 2018e; Onifade and Genc, 2018b, Uludag, Phillips, and Eroglu, 2001). Wade, Gouws, and Phillips, (1987) reported the details of the experimental procedure (Figure 2a). The index is calculated from the formula in Equation [1]. MS Excel is used to calculate the stages and generate the thermogram (Figure $2 b$ ).

Wits-Ehac Index $=($ Stage II slope $/$ XPT $) * 500$

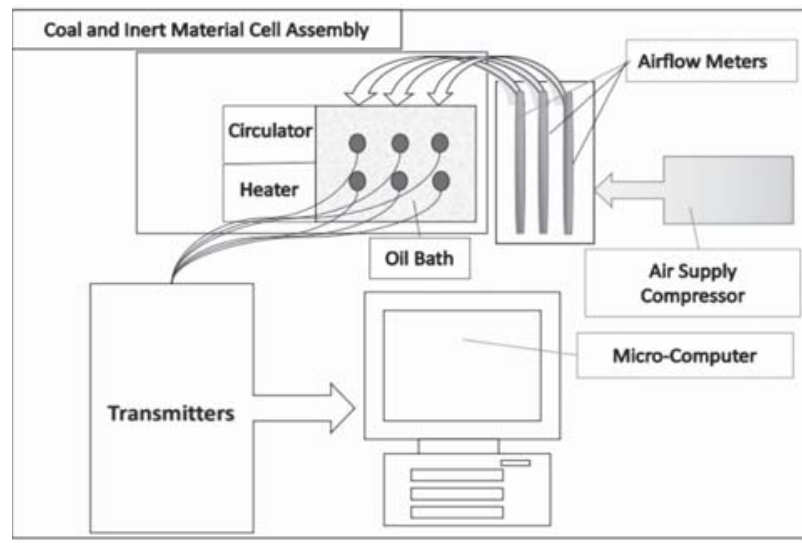

Figure 2a-Wits-Ehac apparatus set-up (Wade, Gouws, and Phillips, 1987)

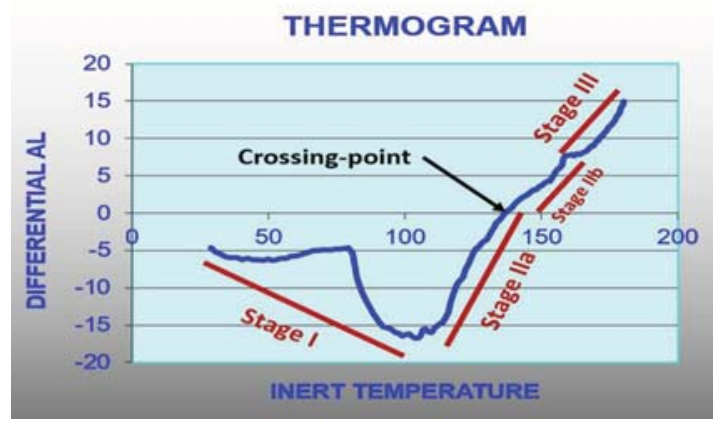

Figure $2 b-A$ typical differential analysis thermogram of a coal sample produced by the Wits-Ehac Index 


\section{Prediction of the spontaneous combustion liability of coals and coal shales}

\section{Wits-CT tests}

The Wits-Ehac Index was developed to test the spontaneous combustion liability of coal. However, the Index failed to produce tangible results during the testing of some coal shales due to their low reactivity (Onifade, Genc, and Carpede, 2018). This is usually the case when the proportions of different organic (macerals) and inorganic matter (mainly crystalline) present in the samples vary. Consequently, a new method and apparatus were developed $n$ the School of Mining Engineering, University of the Witwatersrand. This method is referred to as the Wits-CT test. The liability of various samples to spontaneous combustion was evaluated for 24 hours in ambient air. The details of the experimental procedure are documented by Onifade, Genc, and Carpede (2018). Figure 3 illustrates the experimental set-up. The index is calculated from the formula in Equation [2].

Wits-CT Index $=\left(T_{M} / 24+T_{R}\right) * 0 \mathrm{C}_{\mathrm{ad}}$

where $T_{M}$ is the difference between the sum of the maximum temperatures of each thermocouple in the autoclave and room temperature $\left(22^{\circ} \mathrm{C}\right), T_{R}$ is the difference between the peak temperature and initial temperature during oxidation in degrees Celsius, $\% \mathrm{C}_{\mathrm{ad}}$ is the air-dried percentage of carbon content of the sample, and 24 is the test duration in hours (constant).

\section{Results and analysis}

The results for proximate, elemental analysis, and spontaneous combustion tests conducted on coal and coal shale samples are shown in Tables I and II respectively.

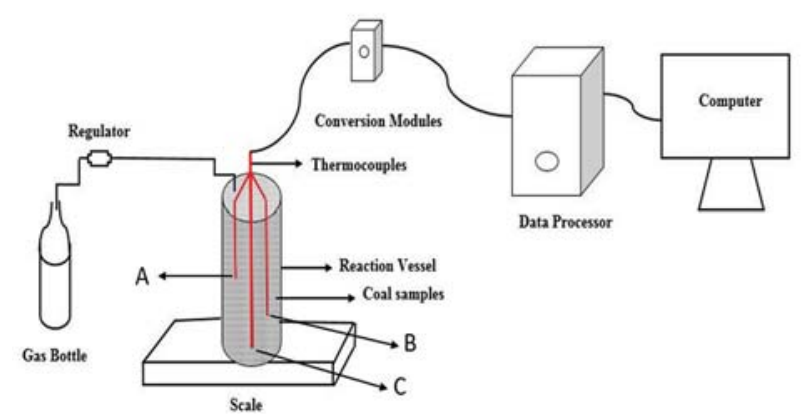

Figure 3-Schematic view of experimental set-up for Wits-CT tests (Onifade, Genc, and Carpede, 2018)

\begin{tabular}{|c|c|c|c|c|c|c|c|c|c|c|c|}
\hline \multirow[t]{2}{*}{ Sample } & \multicolumn{4}{|c|}{ Proximate analysis } & \multicolumn{5}{|c|}{ Ultimate analysis } & \multicolumn{2}{|c|}{ Liability indices } \\
\hline & $\mathbf{M}$ & V & A & FC & C & $\mathrm{H}$ & $\mathbf{N}$ & $\mathbf{S}$ & Oc & WE & WC \\
\hline CA & 2.3 & 23.2 & 28.0 & 46.5 & 54.4 & 3.33 & 1.34 & 1.91 & 8.72 & 4.64 & 6.29 \\
\hline $\mathrm{CB}$ & 2.3 & 21.0 & 20.0 & 56.7 & 61.4 & 3.36 & 1.48 & 1.11 & 10.4 & 4.64 & 6.96 \\
\hline $\mathrm{CC}$ & 2.2 & 24.1 & 33.8 & 39.9 & 47.5 & 3.20 & 1.35 & 3.96 & 7.99 & 4.52 & 5.31 \\
\hline$C D$ & 2.3 & 25.5 & 20.5 & 51.7 & 61.4 & 3.78 & 1.53 & 0.86 & 9.63 & 4.60 & 6.80 \\
\hline CE & 2.3 & 24.3 & 28.6 & 44.8 & 53.6 & 3.41 & 1.25 & 1.08 & 9.76 & 4.76 & 5.42 \\
\hline CF & 2.5 & 23.6 & 46.9 & 27.0 & 35.9 & 3.01 & 0.89 & 3.42 & 7.38 & 4.49 & 3.97 \\
\hline CG & 2.5 & 20.0 & 16.8 & 60.7 & 66 & 3.64 & 1.58 & 0.64 & 8.84 & 4.91 & 7.53 \\
\hline $\mathrm{CH}$ & 2.4 & 26.9 & 18.8 & 51.9 & 65.2 & 4.21 & 1.55 & 2.19 & 5.65 & 4.69 & 7.51 \\
\hline $\mathrm{Cl}$ & 2.1 & 16.7 & 48.4 & 32.8 & 36.1 & 2.55 & 0.85 & 1.22 & 8.78 & 3.82 & 4.05 \\
\hline CJ & 1.9 & 25.7 & 28.1 & 44.3 & 52.4 & 3.13 & 1.35 & 5.30 & 7.82 & 4.46 & 6.61 \\
\hline CK & 1.6 & 22.1 & 13.7 & 62.6 & 69.7 & 4.02 & 1.60 & 0.76 & 8.62 & 4.44 & 9.10 \\
\hline$C L$ & 1.6 & 26.1 & 22.5 & 49.8 & 58.9 & 3.57 & 1.45 & 3.88 & 8.10 & 4.87 & 9.59 \\
\hline $\mathrm{CM}$ & 1.6 & 22.0 & 17.0 & 59.4 & 66.7 & 3.77 & 1.57 & 0.59 & 8.78 & 4.76 & 7.27 \\
\hline $\mathrm{CN}$ & 1.6 & 23.9 & 17.0 & 57.5 & 65.8 & 4.2 & 1.63 & 2.92 & 6.85 & 4.84 & 7.91 \\
\hline
\end{tabular}

Table II

Proximate, elemental analysis, (air-dried,\%), and spontaneous combustion test results for the coal shales

\begin{tabular}{|c|c|c|c|c|c|c|c|c|c|c|c|}
\hline \multirow[t]{2}{*}{ Sample } & \multicolumn{4}{|c|}{ Proximate analysis } & \multicolumn{5}{|c|}{ Ultimate analysis } & \multicolumn{2}{|c|}{ Liability indices } \\
\hline & M & V & A & FC & C & $\mathbf{H}$ & $\mathbf{N}$ & $\mathbf{S}$ & Oc & WE & WC \\
\hline SA & 1.4 & 11.2 & 78.5 & 8.9 & 11.5 & 1.34 & 0.34 & 0.54 & 6.39 & 3.09 & 1.33 \\
\hline SB & 0.9 & 13.9 & 77.2 & 8.0 & 11.0 & 1.27 & 0.40 & 1.56 & 7.67 & 3.06 & 1.30 \\
\hline SC & 1.1 & 12.7 & 74.6 & 11.6 & 13.8 & 1.60 & 0.42 & 0.35 & 8.13 & - & 0.91 \\
\hline SD & 1.6 & 13.3 & 77.3 & 7.8 & 10.8 & 1.43 & 0.32 & 2.53 & 6.02 & 3.27 & 0.70 \\
\hline SE & 1.7 & 15.9 & 68.4 & 14.0 & 15.8 & 1.78 & 0.41 & 6.90 & 5.01 & 3.73 & 1.60 \\
\hline SF & 0.9 & 13.5 & 76.9 & 8.7 & 11.8 & 1.40 & 0.43 & 0.46 & 8.11 & 3.10 & 1.36 \\
\hline SG & 0.8 & 10.7 & 84.3 & 4.2 & 6.02 & 1.04 & 0.29 & 0.73 & 6.83 & - & 0.67 \\
\hline $\mathrm{SH}$ & 0.8 & 8.5 & 88.7 & 2.0 & 2.66 & 0.96 & 0.09 & 0.41 & 6.38 & - & 0.27 \\
\hline SI & 1.0 & 11.9 & 79.6 & 7.5 & 9.12 & 1.41 & 0.26 & 0.22 & 8.39 & - & 0.95 \\
\hline SJ & 0.9 & 11.9 & 86.9 & 0.3 & 3.42 & 0.75 & 0.08 & 0.75 & 7.19 & - & 0.42 \\
\hline SK & 1.0 & 11.7 & 79.1 & 8.2 & 9.75 & 1.73 & 0.41 & 0.16 & 7.85 & 2.98 & 1.18 \\
\hline SL & 1.0 & 16.0 & 74.0 & 9.0 & 10.5 & 2.14 & 0.39 & 0.12 & 11.85 & 2.99 & 1.34 \\
\hline SM & 0.8 & 11.7 & 76.9 & 10.6 & 12.5 & 1.61 & 0.52 & 0.24 & 7.43 & - & 1.44 \\
\hline SN & 1.5 & 16.6 & 51.5 & 30.4 & 33.7 & 2.87 & 0.96 & 0.31 & 9.16 & 3.77 & 3.99 \\
\hline
\end{tabular}

$\mathrm{M}=$ moisture (\%), $\mathrm{V}=$ volatile matter (\%), $\mathrm{A}=$ ash (\%), $\mathrm{FC}=$ fixed carbon determined by difference, $\mathrm{C}=$ carbon $(\%), \mathrm{H}=\mathrm{hydrogen}(\%), \mathrm{N}=$ nitrogen $(\%), \mathrm{S}=$ sulphur $(\%)$, Oc =calculated oxygen (\%), WE=Wits-Ehac Index, and WC=Wits-CT Index. 


\section{Prediction of the spontaneous combustion liability of coals and coal shales}

The moisture content varies between $1.6 \%$ and $2.5 \%$ for coal, and $0.8 \%$ and $1.7 \%$ for coal shales. The samples have a low moisture content and are thus more liable to spontaneous combustion. The low moisture content could be caused by the amount of water molecules absorbed on the external surface and internal open pore surface of the coals and coal shales. A low content of both physically and chemically absorbed water is one of the characteristics of higher rank coals. Similar studies are documented by Beamish and Hamilton (2005), McPherson (1993), and Onifade and Genc (2018d). The coal shales have low moisture contents similar to the tested coal samples. The moisture content of coals $\mathrm{CG}$ to $\mathrm{CJ}$ varies between $1.9 \%$ and $2.5 \%$, between $2.2 \%$ and $2.3 \%$ for CA to $\mathrm{CC}$, and between $2.3 \%$ to $2.5 \%$ for $\mathrm{CD}$ to $\mathrm{CF}$. CK to $\mathrm{CN}$ have the lowest moisture content (all with 1.6\%), while coals CF and $\mathrm{CG}$ have the highest moisture contents, followed by $\mathrm{CH}$ and then $\mathrm{CA}, \mathrm{CB}, \mathrm{CD}$, and $\mathrm{CE}$. It was found that the samples have approximately the same moisture contents and are more liable to spontaneous combustion, except for samples CF and $\mathrm{CI}$, with lower liability indices.

Coal shales SE, SD, and SN have approximately the same moisture contents. Coal shale SN is more liable to spontaneous combustion than the other coal shales. This may be due to the presence of unidentified mineral matter that promotes the self-heating rate (Onifade and Genc, 2018d). The study shows that an increase in moisture content of coal and coal shales is enough to provide a high heat loss from evaporation, as the coal temperature increases during the oxidation reaction.

The volatile matter content varies between $16.7 \%$ and $26.9 \%$ for the coals and $6.5 \%$ and $16.6 \%$ for the coal shales. The volatile matter content for the coals is greater than $20 \%$, except for sample CI (16.7\%). Coals with a high volatile matter content are more liable to undergo spontaneous combustion, except for sample CF, which has a low Wits-CT Index as indicated in Table I. This is in line with the studies reported by Banerjee (2000) and Onifade and Genc (2018d). Among the coal shales, the highest volatile matter content is found in SN and SE, which are more liable to undergo spontaneous combustion compared to the other coal shales.

The ash content ranges between $13.7 \%$ and $48.4 \%$ for the coals, and $51.5 \%$ and $88.7 \%$ for the coal shales. It is known that the physical and chemical properties of coal changes during oxidation (Taylor et al., 1998). The variation in ash content for samples from the same seam may be attributed to different proportions of mineral matter. The ash contents of coals $\mathrm{CF}$ and $\mathrm{CI}$ are high and these samples have low liability indices, while coals with low ash content have higher indices. The low and high liability indices of the coal samples could be due to the heat absorbing capacity of the minerals within the coal (Onifade and Genc, 2018d). Coal shales SN and SE have the lowest ash contents and the highest liability indices. Coal shales SH, SJ, and SG have high ash contents and indicated very low liability indices with the Wits-CT Index. Their liability indices could not be determined with the Wits-Ehac Index because of their low reactivity (Onifade et al., 2018).

The carbon content varies between $35.9 \%$ and $69.7 \%$ for the coals, and $2.66 \%$ and $33.7 \%$ for the coal shales. Coals CF and $\mathrm{CI}$ have the lowest carbon contents and the lowest liability indices, whereas coals with high carbon contents have high liability indices (Onifade and Genc, 2018c). Coal shales SN and SE have the highest carbon content and the highest liability indices. It was found that coal shales with high and low carbon contents show similar characteristics towards spontaneous combustion as coals containing high and low carbon contents.

Coals $\mathrm{CI}$ and $\mathrm{CF}$ have the lowest hydrogen $(2.55 \%$ and $3.01 \%$ ) and the lowest liability indices, while coals $\mathrm{CN}$ and $\mathrm{CH}$ have medium-high hydrogen contents of $4.20 \%$ and high spontaneous combustion indices. Coal CN has the highest nitrogen content and a high liability index, while coals $\mathrm{CI}$ and CF have the lowest nitrogen contents of $0.85 \%$ and $0.89 \%$ and low liability indices. Coal shale SN has the highest hydrogen and nitrogen content of $2.87 \%$ and $0.96 \%$, respectively and high liability indices compared to the other coal shales, while coal shale SJ, with the lowest hydrogen $(0.75 \%)$ and nitrogen content $(0.08 \%)$, has a low liability index. Coal $\mathrm{CH}$ has the lowest oxygen at $5.65 \%$, and the highest oxygen content is found in coal CB (10.35\%). Coal shale SE has the lowest oxygen content of $5.01 \%$ while coal shale SL has the highest oxygen content of $11.85 \%$. This study found that oxygen content may have no influence on the spontaneous combustion liability index. Hence, the oxygen content of coal and coal shale does not seem to show a direct relationship to the readiness with which they absorb oxygen.

\section{Statistical analysis}

The initial evaluation of the intrinsic factors affecting spontaneous combustion of coals and coal shales was based on data obtained from spontaneous combustion liability tests and selected intrinsic factors obtained in the laboratory. The data was grouped into dependent and independent variables in order to facilitate the analyses. The statistical analysis was conducted by correlating coal and coal shale intrinsic factors as independent variables, with the values of the Wits-CT and Wits-Ehac indices as dependent variables. The R-squared values and the correlation coefficients were used to measure the trends and determine any significant relationships between the intrinsic properties and the Wits-Ehac Index and Wits-CT Index (Tables IV and V). The study interpreted the linear relationship between the intrinsic properties and spontaneous combustion liability index based on the criteria set by Onifade and Genc (2018b) as shown in Table III. Detailed descriptions of the statistical method and criteria are given by Onifade and Genc, (2018b).

\section{Linear regression analysis}

Data obtained from spontaneous combustion liability tests and intrinsic factors for the 28 coal and coal shale samples was analysed statistically. Tables IV and V presents the results of the linear regression analyses for both the coal and coal shale samples. Parentheses indicate a negative value.

The analysis of the independent and dependent variable pairs (moisture/Wits-Ehac Index; moisture/Wits-CT Index; volatile matter/Wits-Ehac Index; volatile matter/Wits-CT Index; ash/Wits-Ehac Index; ash/Wits-CT Index etc.) indicated similar trends in some cases. The spontaneous combustion liability index increases with increasing volatile matter, carbon, and hydrogen and decreases with increasing ash for the coals and coal shales. The proximate and ultimate analyses indicated that moisture, ash, carbon, hydrogen, and 


\section{Prediction of the spontaneous combustion liability of coals and coal shales}

\begin{tabular}{|c|c|c|}
\hline \multicolumn{3}{|r|}{ coal shales (Onifade and Genc, 2018b) } \\
\hline Category & Criterion & Remarks \\
\hline $\begin{array}{l}1 \\
2 \\
3 \\
4 \\
5 \\
6\end{array}$ & $\begin{array}{c}\text { Correlation coefficient/R-squared value between } 0.95 \text { to } 1 \text { or }-0.95 \text { to }-1 \\
\text { Correlation coefficient/R-squared value between } 0.51 \text { to } 0.94 \text { or }-0.51 \text { to }-0.94 \\
\text { Correlation coefficient/R-squared value between } 0.25 \text { to } 0.50 \text { or }-0.25 \text { to }-0.50 \\
\text { Correlation coefficient/R-squared value between } 0.1 \text { or } 0.24 \text { or }-0.1 \text { to }-2.24 \\
\text { Correlation coefficient/R-squared value less than } 0.1 \text { but not zero } \\
\text { Correlation coefficient of zero }\end{array}$ & $\begin{array}{l}\text { Perfect positive or negative linear relationship } \\
\text { Strong positive or negative linear relationship } \\
\text { Moderate positive or negative linear relationship } \\
\text { Weak positive or negative linear relationship } \\
\text { Very weak positive or negative linear relationship } \\
\text { No linear relationship }\end{array}$ \\
\hline
\end{tabular}

\begin{tabular}{|c|c|c|c|c|}
\hline \multicolumn{5}{|c|}{$\begin{array}{l}\text { Relationships between independent (wt. \%, air-dried) and dependent variables obtained from linear redgression } \\
\text { for coal samples }\end{array}$} \\
\hline \multirow[t]{2}{*}{ Independent variable } & \multicolumn{2}{|c|}{ Dependent variables $\mathrm{R}$-squared values } & \multicolumn{2}{|c|}{ Dependent variables correlation coefficients } \\
\hline & Wits-Ehac Index & Wits-CT Index & Wits-Ehac Index & Wits-CT Index \\
\hline $\begin{array}{l}\text { Moisture } \\
\text { Volatile matter } \\
\text { Ash } \\
\text { Carbon } \\
\text { Hydrogen } \\
\text { Nitrogen } \\
\text { Total sulphur } \\
\text { Oxygen }\end{array}$ & $\begin{array}{l}0.0041 \\
0.2666 \\
0.4739 \\
0.4318 \\
0.4377 \\
0.4823 \\
0.0047 \\
0.0001\end{array}$ & $\begin{array}{l}0.3418 \\
0.1071 \\
0.7500 \\
0.7336 \\
0.5703 \\
0.7026 \\
0.0047 \\
0.0103\end{array}$ & $\begin{array}{c}(0.0637) \\
0.5164 \\
(0.6884) \\
0.6572 \\
0.6616 \\
0.6945 \\
(0.0686) \\
(0.0115)\end{array}$ & $\begin{array}{c}(0.5847) \\
0.3273 \\
(0.8660) \\
0.8565 \\
0.7552 \\
0.8382 \\
(0.1016) \\
(0.0687)\end{array}$ \\
\hline
\end{tabular}

\begin{tabular}{|c|c|c|c|c|}
\hline \multicolumn{5}{|l|}{$\begin{array}{l}\text { Table V } \\
\text { Relationships be }\end{array}$} \\
\hline \multirow[t]{2}{*}{ Independent variable } & \multicolumn{2}{|c|}{ Dependent variables R-squared values } & \multicolumn{2}{|c|}{ Dependent variables correlation coefficients } \\
\hline & Wits-Ehac Index & Wits-CT Index & Wits-Ehac Index & Wits-CT Index \\
\hline $\begin{array}{l}\text { Moisture } \\
\text { Volatile matter } \\
\text { Ash } \\
\text { Carbon } \\
\text { Hydrogen } \\
\text { Nitrogen } \\
\text { Total sulphur } \\
\text { Oxygen }\end{array}$ & $\begin{array}{l}0.5952 \\
0.4082 \\
0.6975 \\
0.6339 \\
0.3358 \\
0.4155 \\
0.3353 \\
0.1031\end{array}$ & $\begin{array}{l}0.2031 \\
0.4763 \\
0.8926 \\
0.9273 \\
0.7742 \\
0.8953 \\
0.0006 \\
0.1052\end{array}$ & $\begin{array}{c}0.7715 \\
0.6389 \\
(0.8352) \\
0.7962 \\
0.5795 \\
0.6446 \\
0.5791 \\
(0.3212)\end{array}$ & $\begin{array}{c}0.4507 \\
0.6901 \\
(0.9448) \\
0.9630 \\
0.8799 \\
0.9462 \\
0.0242 \\
(0.3243)\end{array}$ \\
\hline
\end{tabular}

nitrogen are the factors influencing spontaneous combustion liability of coal based on the Wits-CT Index, while volatile matter, ash, carbon, hydrogen, and nitrogen are the main factors affecting spontaneous combustion liability with the Wits-Ehac Index. In addition, volatile matter, ash, carbon, hydrogen, and nitrogen are the factors influencing spontaneous combustion liability of coal shales, with stronger relationships using the Wits-CT Index, while moisture, volatile matter, ash, carbon, hydrogen, nitrogen, and total sulphur are the factors affecting spontaneous combustion liability of coal shales according to the Wits-Ehac Index. The linear regression indicates that the two spontaneous combustion liability indices show linear relationships with the intrinsic factors for both coal and coal shale samples based on the criteria used, and thus identify the major intrinsic factors affecting spontaneous combustion liability (Table IV and V). Similar findings are documented by Onifade and Genc (2018b). This study indicated that the intrinsic factors of coal and coal-shale may be used to measure spontaneous combustion liability. It was found that of the intrinsic properties considered, only the ash content has a negative effect on spontaneous combustion liability. Figures 4 and 5 illustrate the relationships between intrinsic factors and spontaneous combustion liability indices using linear regression analysis.

\section{Influence of intrinsic factors on spontaneous combustion liability of coals and coal shales}

Figures $4 \mathrm{i}$ and $5 \mathrm{a}$ illustrate the influence of moisture content on the spontaneous combustion liability of coals and coal shales. The results indicated a negative correlation for the 
Prediction of the spontaneous combustion liability of coals and coal shales
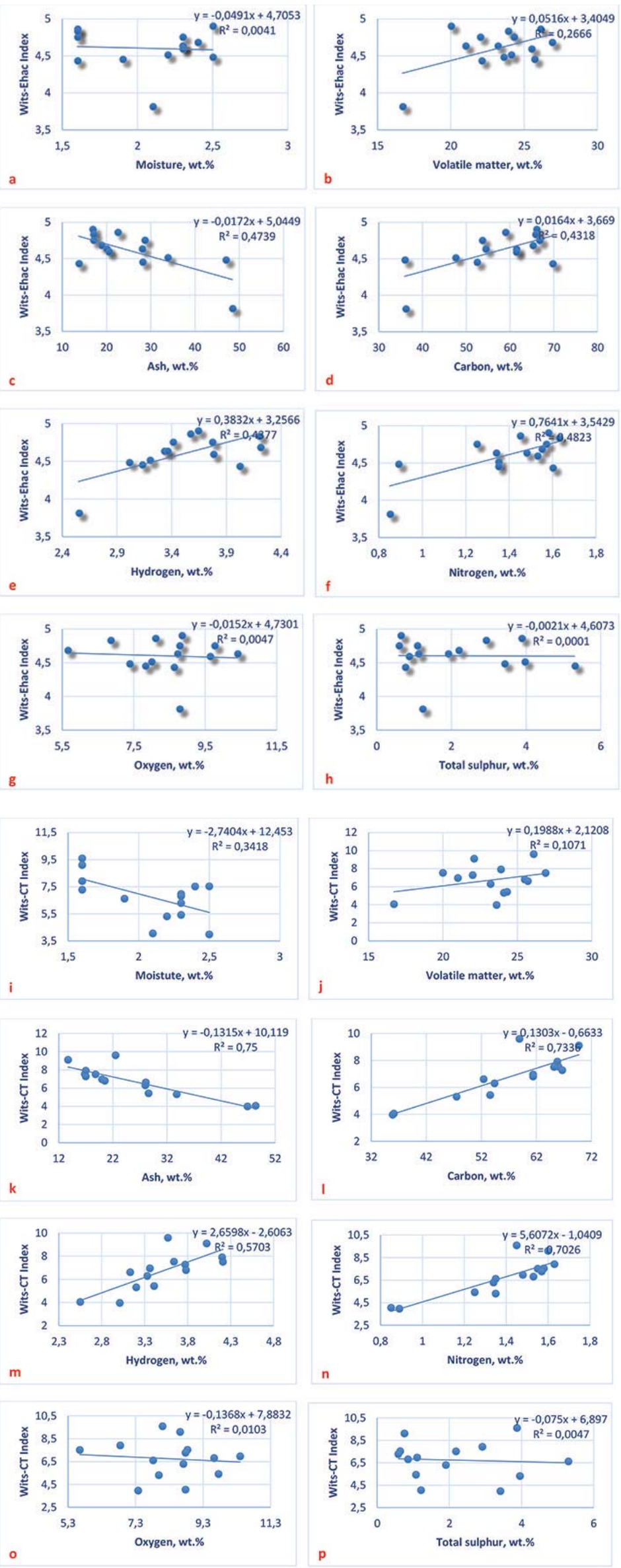

Figure 4-Linear relationships between liability indices (Wits-CT and Wits-Ehac) and intrinsic properties of coal 
Prediction of the spontaneous combustion liability of coals and coal shales
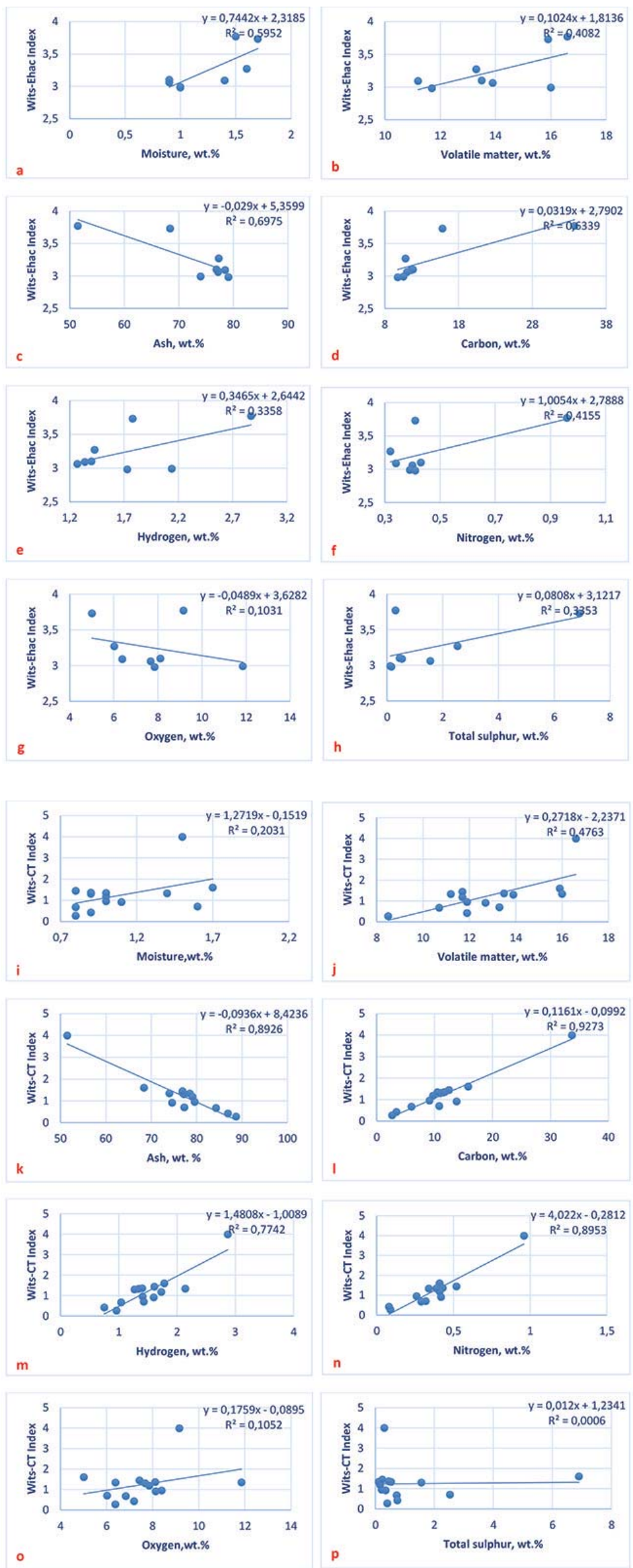

Figure 5-Linear relationships between liability indices (Wits-CT and Wits-Ehac) and intrinsic properties of coal shales 


\section{Prediction of the spontaneous combustion liability of coals and coal shales}

coals and a positive correlation for the coal shales. As the correlation displays an R-squared of 0.3418 for coals, it shows that the linear model has a moderate strength. It is different for the coal shales. Here the R-squared value is 0.5952, higher than for the coals. This indicates that the moisture content of the coal shales has a strong influence on the self-heating potential.

The R-squared value for volatile matter is 0.2666 for coals and 0.4763 for coal shales (Figures $4 \mathrm{~b}$ and $5 \mathrm{j}$ ). This is an indication that volatile matter content has a moderate influence on both coals and coal shales. The self-heating potential tends to increase for both cases but the increase seems to be more pronounced for coal shales than for coals. There is a positive relationship between the volatile matter and spontaneous combustion liability index for both coals and coal shales. Hence, as the volatile matter increases, the self-heating potential is likely to increase. Similar results are reported by Onifade and Genc, (2018b).

There is a negative relationship between the ash content and spontaneous combustion liability index for both coals and coal shales. A similar trend is reported by Onifade and Genc (2018b). The R-squared value is 0.75 for coals and 0.8926 for coal shales (Figures $4 k$ and $5 k$ ). Therefore, the relationship between the ash content and spontaneous combustion liability index seems to be strong.

The R-squared value for carbon content is 0.7336 for coals and 0.9273 for coal shales (Figures 41 and 51 ). The relationship between carbon content and spontaneous combustion liability seems to be strongly positive. Therefore, as the carbon content increases, the self-heating potential is likely to increase. Onifade and Genc, (2018b) reported similar results.

The R-squared value for the hydrogen content is 0.5703 for coals and 0.7742 for coal shales (Figures $4 \mathrm{~m}$ and $5 \mathrm{~m}$ ). The relationships between the hydrogen content and spontaneous combustion liability index for coals and coalshales are strongly positive. Hence, as the hydrogen content increases, the self-heating for both coals and coal shales may increase. Similar results were reported by Onifade and Genc, (2018b).

The R-squared value for the nitrogen content is 0.7026 for coals and 0.8953 for coal shales (Figures $4 n$ and $5 n$ ). The relationships between the nitrogen content and spontaneous combustion liability index for coals and coal shales are both strong and positive. This indicates that as the nitrogen content increases, the self-heating potential is likely to increase, but this effect seems to be more pronounced for coal shales than for coals.

Total sulphur showed a negative correlation for the coals and a positive correlation for the coal shales (Figures $4 \mathrm{p}$ and $5 \mathrm{~h}$ ). The R-squared value of 0.0047 for coals (Figure $4 \mathrm{p}$ ) indicates that the linear model does not fit well. This is not the same with the coal shales. Here, the R-squared value is slightly higher, 0.3353 , than for the coals, thus indicating a moderate influence on self-heating potential, as opposed to the very weak effect for coals. Onifade and Genc, (2018b) reported similar results.

The calculated oxygen showed a negative correlation for the coals and a positive correlation for the coal shales. The correlation (Figure 40) has an R-squared value of 0.0103 for coals, indicating that the linear model does not fit well. The $\mathrm{R}$-squared for coal shales is slightly higher, 0.1052 (Figure $50)$. Hence although the influence of this factor is very weak, it is more pronounced for coal-shales than for coals.

\section{Multiple regression analysis}

Multiple regression analysis was used to establish models for predicting the spontaneous combustion liability index of coals and coal shales. The models were developed by using eight independent variables (Table VI). A similar study by Onifade and Genc $(2018 b)$ indicated that the use of a single variable to predict the spontaneous combustion liability is unreliable. The study indicated that the influence of each intrinsic factor on spontaneous combustion liability varied, based on the linear regression. This motivated the need for further development of the models. The model that provides the highest correlation coefficient and lowest standard error of estimate was determined through multiple regression calculations.

The most reliable predictions of spontaneous combustion liability of the 14 coals and 14 coal shales are provided by the four models listed in Table VI. The developed models indicated a high correlation coefficient and low standard error. The study indicated that the Wits-Ehac Index and intrinsic properties show correlation coefficients of 0.815 and 0.998 , and low standard errors of 0.254 and 0.011 for the coals and coal shales respectively, while the Wits-CT Index shows higher correlation coefficients of 0.937 and 0.991, and

Table VI

Models developed by multiple regression analysis

\begin{tabular}{|c|c|c|c|}
\hline Formula no. & Models developed & $\mathbf{R}^{\star}$ & SEE $†$ \\
\hline All coals $(A)$ & $\begin{aligned} \mathrm{WE}= & 154.49-1.23 \mathrm{M}_{\mathrm{ad}}-0.01 \mathrm{~V}_{\mathrm{ad}}-1.54 \mathrm{~A}_{\mathrm{ad}}-1.52 \mathrm{C}_{\mathrm{ad}} \\
& -1.01 \mathrm{H}_{\mathrm{ad}}-2.10 \mathrm{~N}_{\mathrm{ad}}-1.4 \mathrm{~S}_{\mathrm{ad}}-1.41 \mathrm{O}_{\mathrm{c}}\end{aligned}$ & 0.815 & 0.254 \\
\hline All coals $(B)$ & $\begin{aligned} \mathrm{WC}= & 968.39-10.37 \mathrm{M}_{\mathrm{ad}}-0.04 \mathrm{~V}_{\mathrm{ad}}-9.70 \mathrm{~A}_{\mathrm{ad}}-9.43 \mathrm{C}_{\mathrm{ad}} \\
& -9.62 \mathrm{H}_{\mathrm{ad}}-15.30 \mathrm{~N}_{\mathrm{ad}}-9.13 \mathrm{~S}_{\mathrm{ad}}-9.50 \mathrm{O}_{\mathrm{c}}\end{aligned}$ & 0.937 & 0.931 \\
\hline All coal shales $(C)$ & $\begin{aligned} \mathrm{WE}= & -2761+25.98 \mathrm{M}_{\mathrm{ad}}+0.51 \mathrm{~V}_{\mathrm{ad}}+27.65 \mathrm{~A}_{\mathrm{ad}}+27.68 \mathrm{C}_{\mathrm{ad}} \\
& +29.6 \mathrm{H}_{\mathrm{ad}}+21.73 \mathrm{~N}_{\mathrm{ad}}+27.17 \mathrm{~S}_{\mathrm{ad}}+26.83 \mathrm{O}_{\mathrm{c}}\end{aligned}$ & 0.998 & 0.011 \\
\hline All coal shales (D) & $\begin{aligned} \mathrm{WC}= & -8396.61+79.12 \mathrm{M}_{\mathrm{ad}}+1.16 \mathrm{~V}_{\mathrm{ad}}+83.99 \mathrm{~A}_{\mathrm{ad}}+84.17 \mathrm{C}_{\mathrm{ad}} \\
& +88.71 \mathrm{H}_{\mathrm{ad}}+70.40 \mathrm{~N}_{\mathrm{ad}}+82.88 \mathrm{~S}_{\mathrm{ad}}+82.18 \mathrm{O}_{\mathrm{c}}\end{aligned}$ & 0.991 & 0.193 \\
\hline
\end{tabular}

${ }^{*} \mathrm{R}=$ correlation coefficient, $\uparrow \mathrm{SEE}=$ standard error of estimate 


\section{Prediction of the spontaneous combustion liability of coals and coal shales}

standard errors of 0.931 and 0.193 . The models developed for the Wits-Ehac Index give lower standard errors of estimate and correlation coefficients than the Wits-CT Index for both coals and coal shales (Table VI). Therefore, the WitsEhac Index can yield more reliable results based on a low of standard error, while the Wits-CT Index can also be used to obtain suitable results based on high correlation coefficients. This indicates that the two liability indices can be used to predict the spontaneous combustion propensity of coals and coal shales. The models indicate that spontaneous combustion occurs due to the combined effect of various intrinsic factors. Onifade and Genc (2018b) reported similar results.

\section{Validation of predicted model results}

The results of the actual Wits-Ehac and Wits-CT indexes for coals and coal shales are presented in Tables VII and VIII.

The predicted spontaneous combustion liability indices (Wits-Ehac and Wits-CT) were validated with the actual indices, and the results are in line (Tables VII and VIII).

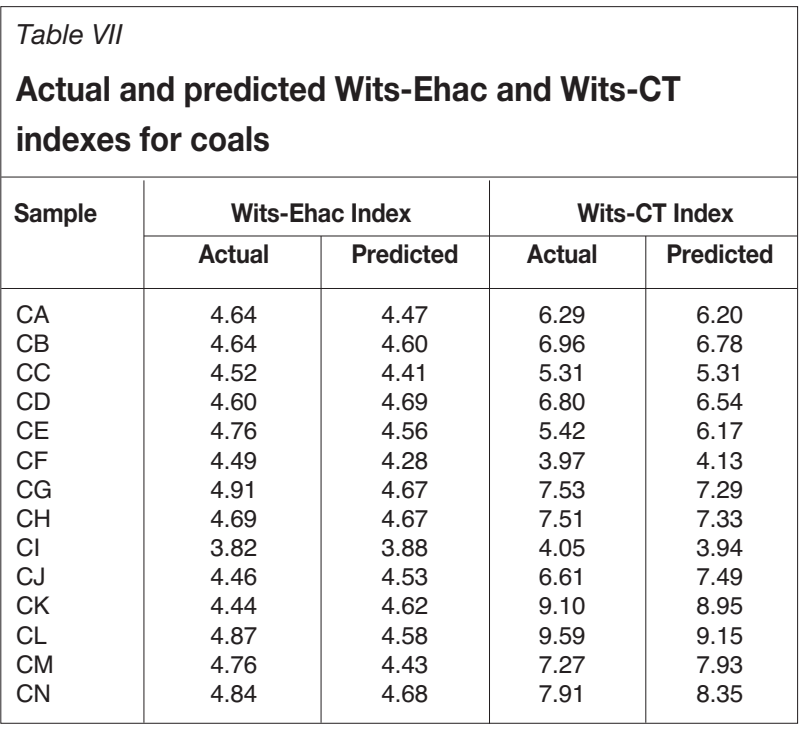

\begin{tabular}{|c|c|c|c|c|}
\hline \multicolumn{5}{|c|}{$\begin{array}{l}\text { Table VIII } \\
\text { Actual and predicted Wits-Ehac and Wits-CT } \\
\text { indexes for coal shales }\end{array}$} \\
\hline \multirow[t]{2}{*}{ Samples } & \multicolumn{2}{|c|}{ Wits-Ehac Index } & \multicolumn{2}{|c|}{ Wits-CT Index } \\
\hline & Actual & Predicted & Actual & Predicted \\
\hline SA & 3.09 & 3.10 & 1.33 & 1.01 \\
\hline SB & 3.08 & 2.99 & 1.30 & 1.06 \\
\hline SC & - & 2.85 & 0.91 & 0.99 \\
\hline SD & 3.27 & 3.18 & 0.70 & 0.67 \\
\hline SE & 3.73 & 3.37 & 1.60 & 1.50 \\
\hline SF & 3.10 & 3.05 & 1.36 & 1.37 \\
\hline SG & - & 2.94 & 0.67 & 0.62 \\
\hline $\mathrm{SH}$ & - & 2.99 & 0.27 & 0.14 \\
\hline SI & - & 2.90 & 0.95 & 0.66 \\
\hline SJ & - & 2.72 & 0.42 & 0.19 \\
\hline SK & 2.98 & 3.02 & 1.18 & 1.05 \\
\hline SL & 2.99 & 2.89 & 1.34 & 1.19 \\
\hline SM & - & 2.86 & 1.44 & 1.13 \\
\hline SN & 3.77 & 3.63 & 3.99 & 3.98 \\
\hline
\end{tabular}

Twenty-eight samples evaluated in this work have confirmed the consistency of the developed models. The Wits-Ehac indices for coal shales SC, SG, SH, SI, SJ, and SM, which were not obtained by the actual Wits-Ehac Index due to their low reactivities, were successfully predicted with the models. The models present a high level of confidence as they produced results in line with the actual liability indices.

\section{Conclusion}

The intrinsic properties of coal shales and coals could be used as a measure of the spontaneous combustion risk in coal mines. using linear regression. Moisture, volatile matter, ash, carbon, hydrogen, and nitrogen contents indicate better linear relationships with the spontaneous combustion liability index for coals, while volatile matter, ash, carbon, hydrogen, nitrogen, and total sulphur indicate better linear relationships with the spontaneous combustion liability index for coal shales. Multiple regression analysis shows that the WitsEhac Index and Wits-CT Index have high correlation coefficients with the intrinsic factors and a low standard error for both coals and coal shales. The spontaneous combustion liability of coals and coal shales can be predicted by a model consisting of various intrinsic factors. The predicted spontaneous combustion liability indices (Wits-Ehac and Wits-CT Index) were validated with the actual indices. Further research is under way towards establishing a generalized model involving the cumulative effect of other intrinsic properties such as petrographic composition and mineral matter.

\section{Acknowledgements}

This research was funded by Coaltech and the Julian Baring Scholarship Fund (JBSF). The work presented here is part of a $\mathrm{PhD}$ research study in the School of Mining Engineering at the University of the Witwatersrand.

\section{References}

AKANDE, J.M. and ONIFADE. M. 2013. Modeling of Okaba underground coal mining ventilation system. International Journal of Engineering and Technology, vol. 3, no. 7. pp. 766-772.

AKANDE, J.M., OnIFAdE, M., and AladejARE, A.E. 2013. Determination of airflow distributions in Okaba underground coal mine. Journal of Mining World Express, vol. 2, no. 2. pp. 40-45.

ASTM D-3173. Standard test methods for moisture in the analysis sample of coal and coke. ASTM International, West Conshohocken, PA.

ASTM D-3174. Standard test method for ash in the analysis sample of coal and coke from coal and standard classification of coals by rank. ASTM International, West Conshohocken, PA.

ASTM D-3175. Standard test method for volatile matter in the analysis sample of coal and coke. ASTM International, West Conshohocken, PA.

BAnERJEe, S.C. 2000. Prevention and Combating Mine Fires. Oxford and IBH Publishing, India. p. 33.

BANERJEE, S.C. 1985. Spontaneous Combustion of Coal and Mine Fires. Oxford and IBH Publishing, India.

BEAMISH, B.B. and BLAZAK, D.G. 2005. Relationship between ash content and R70 self-heating rate of callide coal. International Journal of Coal Geology, vol. 64. pp. 126-132.

CARRAS, J. and Young, B. 1994. Self-heating of coal and related materials: models, application and test methods. Progress in Energy and Combustion Science, vol. 20, no. 1. pp. 1-15.

Dullien, F. 1979. Porous Media Fluid Transport and Pore Structure. Academic Press. p. 79.

EROGLU, H.N. 1992. Factors affecting spontaneous combustion liability index. $\mathrm{PhD}$ thesis, University of the Witwatersrand, Johannesburg, South Africa. pp. 157-158. 


\section{Prediction of the spontaneous combustion liability of coals and coal shales}

Falcon, R.M.S. 2004. The constitution of coal and its inherent capacity to selfheat as applied to an integrated spontaneous combustion risk. Final Proceedings of the International Conference in Spontaneous Combustion. Fossil Fuel Foundation and SABS, Johannesburg. pp. 8-9.

Genc, B., OnIFADE, M., and СоoK, A. 2018. Spontaneous combustion risk on South African coalfields: Part 2. Proceedings of the 21st International Coal Congress of Turkey 'ICCET', Zonguldak, Turkey, 11-13, April 2018. pp. $13-25$.

Genc, B. and Соок, A. 2015. Spontaneous combustion risk in South African coalfields. Journal of the Southern African Institute of Mining and Metallurgy, vol. 115. pp. 563-568.

Gouws, M.J. and WADE, L. 1989. The self-heating liability of coal: Predictions based on simple indices. Mining Science and Technology, vol. 9. pp. $75-80$.

GunEy, M. 1968. Oxidation and spontaneous combustion of coal - review of individual factors. Colliery Guardian, vol. 216, no. 105-110. pp. 137-143.

ISO 12902:2001. Determination of total carbon, hydrogen and nitrogen. International Organization for Standardization, Geneva.

KAYмAKсI, E. and DidARI, V. 2002. Relations between coal properties and spontaneous combustion parameters. Turkish Journal of Engineering and Environmental Sciences, vol. 26, no. 1. pp. 59-64.

KIM, A.G. 1977. Laboratory studies on spontaneous heating of coal. IC 8756. US Bureau of Mines.

KucuK, A., Kadioglu, Y., and Gulaboglu, M.S. 2003. A study of spontaneous combustion characteristics of a Turkish lignite: particle size, moisture of coal, humidity of air. Combustion and Flame, vol. 133, no. 3. pp. 255-261.

McPherson, M.J. 1993. Subsurface Ventilation and Environmental Engineering. University Press. p. 23.

OnIFADE, M. and Genc, B. 2018a. A review of spontaneous combustion studiesSouth African context, International Journal of Mining, Reclamation and Environment. https://doi.org/10.1080/17480930.2018.1466402

ONIFADE, M. and Genc, B. 2018b. Modelling spontaneous combustion liability of carbonaceous materials. International Journal of Coal Science and Technology, vol. 52. pp. 191-212. https://doi.org/10.1007/s40789-0180209-2,
Onifade, M. and Genc, B. 2018c. Spontaneous combustion of coals and coalshales. International Journal of Mining Science and Technology. https://doi.org/10.1016/j.ijmst. 2018.05.013

OnIFADE, M. and GENc, B. 2018d. Establishing relationship between spontaneous combustion liability indices. Proceedings of the 21st International Coal Congress of Turkey 'ICCET', Zonguldak, Turkey, 11-13 April 2018. pp. 1-11.

OnIFAde, M. and Genc, B. 2018e. Prediction of the spontaneous combustion liability of coal and coal-shale using statistical analysis. Proceedings of the Society of Mining Professors, 6th Regional Conference, Johannesburg, South Africa, 12-13 March 2018. pp. 63-82.

Onifade, M., Genc, B., and Carpede, A. 2018. A new apparatus to establish the spontaneous combustion propensity of coals and coals. International Journal of Mining Science and Technology. https://doi.org/10.1016/ j.ijmst.2018.05.012

PANigrahi, D.C. and SAHU, H.B. 2004. Classification of coal seams with respect to their spontaneous heating susceptibility - a neural network approach. Geotechnical and Geological Engineering, vol. 22. pp. 457-476.

PANIGRAHI, D.C. and SAXENA, V.K. 2001. An investigation into spontaneous combustion characteristics of coals using differential thermal analysis. Proceedings of the 7th International Mine Ventilation Congress, Krakow, Poland, 17-22 June 2001. EMAG, Cracow. pp. 495-500.

Ren, T.X., EdWARds, J.S., and Clarke, D. 1999. Adiabatic oxidation study on the propensity of pulverized coal to spontaneous combustion. Fuel, vol. 78 . pp. $1611-1620$.

Stracher, G.B. and TAYLoR, T.P. 2004. Coal fires burning out of control around the world: thermodynamic recipe for environmental catastrophe. International Journal of Coal Geology, vol. 59, no. 1. pp. 7-17.

Uludag, S., Phillips, H.R., and Eroglu, H.N. 2001. Assessing spontaneous combustion risk in South African coal mining by using a GIS tool. Proceedings of the 17th International Mining Conference and Exhibition, Turkey. Chamber of Mining Engineers of Turkey, Ankara. pp. 243-249.

WAdE, L., Gouws, M.J., and PHILLIPS, H.R. 1987. An apparatus to establish the spontaneous combustion propensity of South African coals. Proceedings of the Symposium on Safety in Coal Mines, CSIR, Pretoria. pp. 7.1-7.2.
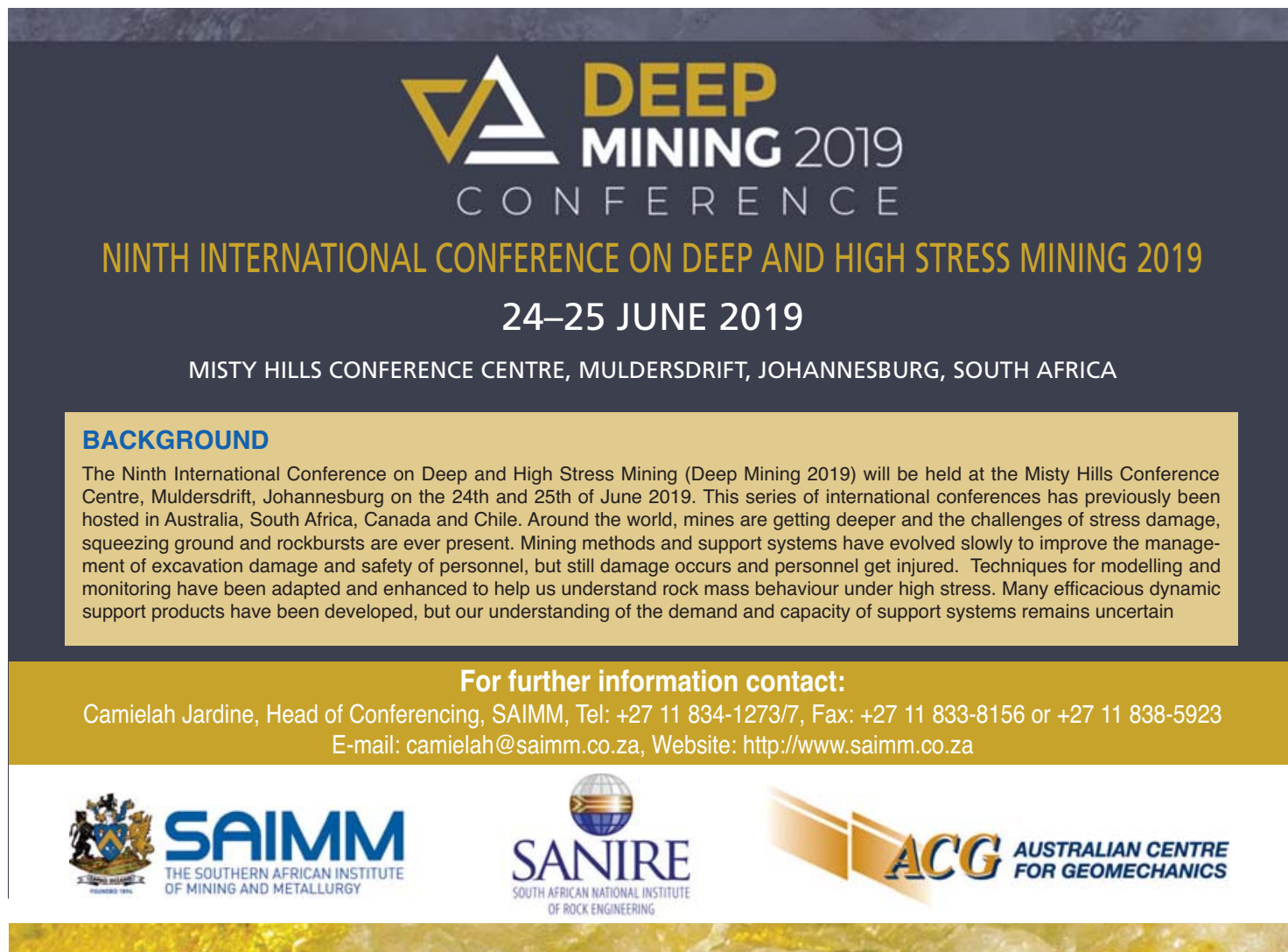